\title{
Melting of 'Big Top' Nectarine Fruit: Some Physiological, Biochemical, and Molecular Aspects
}

\author{
Alessandra Ghiani, Noemi Negrini, Silvia Morgutti', Federica Baldin, Fabio F. Nocito, \\ Anna Spinardi, Ilaria Mignani, Daniele Bassi, and Maurizio Cocucci \\ Dipartimento di Produzione Vegetale, University of Milan, via Celoria 2, 20133 I-Milan, Italy
}

\begin{abstract}
Additional Index words. endo-PG expression, endo-PG activity, Pp-endo-PG gene, ethylene, flesh texture, peach, Prunus persica, ripening

ABstract. 'Big Top' nectarine [Prunus persica (L.) Batsch] has appreciable keeping quality because it resembles, at ripening, the stony hard $(\mathrm{SH})$ peach $(P$. persica) in firmness and crispness but melts at a slow speed at full ripening. We have characterized the postharvest behavior of 'Big Top' fruit, treated or not with ethylene for 5 days after harvest (DAH), and compared it with that of a SH peach ('Ghiaccio'). Pp-ACS1 expression, ethylene evolution, endopolygalacturonase (endo-PG) production, and softening were evaluated and compared with those of the physiologically ripe melting flesh (M) cultivar Bolero. Like 'Bolero', 'Big Top' fruit expressed $P p$ - $A C S 1$ and evolved ethylene but with a 5-day delay. $P$ p-endo-PG expression, production of an active endo-PG, and fruit melting showed a parallel behavior; ethylene treatment enhanced all these features. In SH 'Ghiaccio' Pp-ACS1 expression, ethylene evolution, endo-PG production, and softening were absent during the first $5 \mathrm{DAH}$ in air. 'Ghiaccio' neither expressed $P p$ - $A C S 1$ nor evolved ethylene even after ethylene treatment but responded by accumulating $P$ p-endo-PG transcripts and an active endo-PG protein, with flesh melting. A 'Big Top' Pp-endo-PG clone showed several single nucleotide (SNP) and insertion-deletion (InDel) polymorphisms in comparison with the M Pp-endo-PG clone of 'Bolero' and substantial similarity with the Pp-endo-PG clone of 'Ghiaccio'. In 'Big Top', we identified a peculiar SNP (bp 348) and InDels shared with 'Ghiaccio', possibly suitable for discriminating among different genotypes. Overall, the data confirm the pivotal role of ethylene in the regulation of endo-PG production and in the determination of peach flesh texture and support the evidence that 'Big Top' could be classified as a melting (slow-melting) phenotype.
\end{abstract}

Two main phenotypes of peach fruit in terms of flesh texture and softening are melting flesh and non-melting flesh. The $\mathrm{M}$ texture softens in the last stage of ripening in correspondence to the peak of ethylene evolution (Tonutti et al., 1996), until complete melting. The non-melting flesh (NM) phenotypes show a firm texture even at full ripening, soften slowly when overripe, but never melt (Bailey and French, 1949; Bassi and Monet, 2008). A third, interesting trait is stony hard flesh with almost no ethylene production, crisp fruit, and poor softening (Haji et al., 2003, 2004; Yoshida, 1976), linked to the allelic configuration at an $\mathrm{Hd}$ locus (Haji et al., 2005). The extremely low ethylene production by $\mathrm{SH}$ fruit seems to be the result of reduced expression of the gene 1-aminocyclopropane-1carboxylic acid synthase 1 [Pp-ACS1 (Begheldo et al., 2008; Tatsuki et al., 2006, 2007)]. NM and SH peaches have long keeping quality and are expected to become increasingly important in breeding for new fresh-market cultivars because of their postharvest behavior.

'Big Top' nectarines have peculiar softening characteristics, resembling SH fruit in firmness and crispness at harvest but melting at a slow pace and developing ethylene, although in unpredictable fashion from year to year (Bassi and Monet, 2008) at full ripening a few days after harvest. This behavior led a few authors to consider 'Big Top' as a SH subgroup (Gamberini, 2007), whereas others, on the basis of phenotypic observations, suggested categorizing them as a separate melting sub-group [melting very firm (Bassi and Monet, 2008)].

Received for publication 9 Sept. 2010. Accepted for publication 5 Nov. 2010. This research has been funded by the Italian Ministry of University and Research (MIUR), Cofin (PRIN) project no. 2004077043 coordinated by M.C., and by the MASPES Project (D.B.).

${ }^{1}$ Corresponding author. E-mail: silvia.morgutti@unimi.it.
Flesh softening involves the sequential activation of several genes, many of which are under the control of ethylene (Cara and Giovannoni, 2008), responsible for the definition of cell wall structure (Hayama et al., 2006a; Trainotti et al., 2003). Among these genes, a pivotal role is played by endopolygalacturonase (Brummell et al., 2004; Orr and Brady, 1993; Pressey and Avants, 1978). The NM phenotype of some cultivars appears closely associated with a massive deletion in an endo- $P G$ gene with complete lack of expression of the major endo-PG isoform involved in softening (Callahan et al., 2004; Lester et al., 1994, 1996). Conversely, in NM 'Oro A', the expression of the same gene results in weak accumulation of a normal length transcript and little production of endo-PG, suggesting regulation at the transcriptional level (Morgutti et al., 2006). Interestingly, in SH 'Manami' and IFF331 peaches, neither the endo- $P G$ transcript accumulation nor protein functionality seem altered, as suggested by the observation that ethylene-exogenously applied or induced in fruit by cold stress - promotes endo- $P G$ transcription and softening (Begheldo et al., 2008; Haji et al., 2005; Hayama et al., 2006a, 2006b). Thus, results on different peach fruit phenotypes seem to suggest that different events may affect the multiple steps, which lead to endoPG production and softening. In particular, the amounts of ethylene evolution may not always or necessarily represent the only or main factor that controls softening. In fact, NM fruit evolve more ethylene than M ones (Brovelli et al., 1999).

'Big Top' fruit retain flesh firmness on the tree for a longer time than $\mathrm{M}$ ones, allowing full development of organoleptic qualities because of high sugar levels (Iglesias and Echeverria, 2009) coupled to the low acid trait (Monet, 1979). The occurrence of melting a few days after harvest enhances these positive flavor traits, making the fruit appreciated for fresh consumption. 
To further clarify the mechanisms underlying the determination of the peculiar 'Big Top' softening pattern, we studied the fruit postharvest behavior in the absence or presence of ethylene treatment regarding flesh firmness changes, endo- $P G$ gene transcription, and endo-PG production and activity. The results have been compared with those obtained with $\mathrm{SH}$ 'Ghiaccio' subjected to the same treatments and with physiologically ripe (Bassi and Monet, 2008; Cantín et al., 2010) M 'Bolero' fruit.

Firmness (or pace of softening) is a quality trait important in breeding programs, because it is directly related to susceptibility to mechanical damage during postharvest (Crisosto et al., 2001). In the search for molecular markers for the 'Big Top' fruit phenotype, the analysis has been widened to the $\mathrm{Pp}$-endo$P G$ gene, the structure of which has been compared between 'Big Top' and M 'Bolero', NM 'Oro A', and SH 'Ghiaccio' and 'Yumyeong'.

\section{Materials and Methods}

Plant material. Fruit and leaves were obtained from peach accessions producing fruit with diverse phenotypes: 'Big Top'® nectarine (Zaiger's Genetics, Modesto, CA), 'Yumyeong' [bred in Korea by crossing 'Yamatowase' and 'Nunomewase' (Kim et al., 1978)] and selection 193 Q XXVII 111 [SH; 'Ghiaccio' series, derived from self-pollination of 'Yumyeong' (Nicotra et al., 2002)], 'Bolero' (M; from 'Cresthaven' $\times$ 'Flamecrest'), and 'Oro A' (NM; open pollination of 'Diamante'). Trees were grown under integrated pest management growing systems in a peach collection at Castel San Pietro (northern Italy). Fruit were monitored for size and epicarp ground color on the tree during ripening (2007 growing season) and harvested at developmental Stages 3 to 4 (Westwood, 1978). The harvested 'Bolero' fruit covered the range from "immature" (full size, no softening, fruit firmness greater than $35 \mathrm{~N}$ ), to the "ready to buy" stage (fruit firmness $=18$ to $35 \mathrm{~N}$ ), and "ready to eat" stage (physiologically ripe, fruit firmness less than $18 \mathrm{~N}$ ) (Cantín et al., 2010). 'Big Top', which precociously develops an intense peel red color and softens very slowly on the tree (Bassi et al., 2008; Iglesias and Echeverría, 2009), and 'Ghiaccio' fruit were considered ripe and harvested when flesh firmness and soluble solids concentration (SSC) of at least 10 sample fruit on each tree reached values of stonefruit maturity indices satisfactory for postharvest ripening and consumer appreciation (Crisosto, 1994; Liverani et al., 2003). These values ranged from 44 to $53 \mathrm{~N}$ for flesh firmness and were $12 \%$ or greater for SSC.

RIPENING PARAMETERS AND TISSUE SAMPLING. Immediately after harvest, fruit were preliminarily classified based on weight and, where it could be considered a reliable parameter, epicarp ground color as a maturity index (Delwiche and Baumgardner, 1985). Epicarp color parameters were measured at two points with no blush with a reflectance colorimeter (Chromameter CR200; Minolta, Osaka, Japan) (Robertson et al., 1990). The Minolta $a^{*}$ value was taken as representative of the degree of ripening. Fruit within each class were also assessed for flesh firmness (Newtons) and SSC (percent). Firmness was measured after removing a small disc of skin from each cheek of the fruit by a penetrometer with an 8-mm-diameter probe (Effegi, Alfonsine, Italy). SSC in juice pressed from each fruit was assessed using a hand refractometer (N1; Atago, Tokyo, Japan).
Ethylene evolution and ethylene treatments. Five whole, healthy fruit, whose weight and color matched the average values $( \pm 10 \%)$ recorded at harvest (see previously), were placed individually in 1.1-L glass jars in a thermoregulated $\left(20 \pm 1{ }^{\circ} \mathrm{C}\right)$ chamber with $95 \%$ relative humidity. Ethylene analysis by gas chromatograph (Model 3800; DANI Instruments, Cologno Monzese, Italy) was conducted on 1-mL gas samples collected from the headspace of the jars after $1 \mathrm{~h}$ of hermetic closure (Benedetti et al., 2008). Ethylene evolution was monitored every $24 \mathrm{~h}$ for $10 \mathrm{DAH}$.

For ethylene treatments, 10 to 12 fruit were placed in glass containers (total volume $\approx 0.013 \mathrm{~m}^{3}$ ) at $20 \pm 1{ }^{\circ} \mathrm{C}$ and flushed $\left(\approx 0.1 \mathrm{~m}^{3} \cdot \mathrm{h}^{-1}\right)$ with humidified air supplemented, or not, with $100 \mathrm{~mL} \cdot \mathrm{m}^{-3}$ ethylene. The treatments lasted for $5 \mathrm{DAH}$ with daily checks for absence of visible symptoms of decay. At the end of the treatments, fruit flesh firmness was assessed and mesocarp samples were pooled and frozen in liquid $\mathrm{N}_{2}$. At least five fruit from each treatment were used, in the subsequent 10 $\mathrm{DAH}$, to evaluate the time course of endogenous ethylene emission.

RNA ISOLATION AND NORTHERN HYBRIDIZATION ANALYSIS. Total RNA was extracted from frozen mesocarp tissue (10 g) (Loulakakis et al., 1996). Northern blot analysis (20 $\mu \mathrm{g}$ RNA) was conducted with $\left[\alpha-{ }^{32} \mathrm{P}\right] \mathrm{dATP}-$ labeled probes (Morgutti et al., 2006). Specific primers for $P p$-endo- $P G$ [complete coding sequence (Lester et al., 1994)], Pp-ACS1 [AB044662 (Mathooko et al., 2001)], and Pp-ACO1 [AF532976 (Moon and Callahan, 2004)] probes are reported in Table S1. First-strand cDNAs for these genes were synthesized, purified, and cloned from $1 \mu \mathrm{g}$ of total RNA of ripe 'Bolero' fruit (Morgutti et al., 2006). Sequences were determined by Primm (Milan, Italy).

Protein EXtraction AND QUANTIFiCation. Fruit mesocarp was extracted to obtain a fraction enriched in cell wall proteins $\left[\approx 3 \mu \mathrm{g} \cdot \mu \mathrm{L}^{-1}\right.$ enriched proteins (Morgutti et al., 2006)]. Protein samples were used in the original state for non-denaturing polyacrylamide gel electrophoresis (PAGE) with evaluation of in gel PG activity or desalted with a Plus One 2-D Clean-Up Kit (GE Healthcare Europe, Milan, Italy) for sodium dodecyl sulfate (SDS)-PAGE. Protein content was determined (Bradford, 1976) using bovine serum albumin as a standard (Micro-Bio-Rad Protein Assay; Bio-Rad Laboratories, Segrate, Italy).

GEL ELECTROPHORESIS, ENDO-POLYGALACTURONASE ACTIVITY STAining, AND Western BlotTing. Native-PAGE was performed at $4{ }^{\circ} \mathrm{C}$ in a MiniProtean ${ }^{\mathrm{TM}}$ apparatus (Bio-Rad Laboratories) on $10 \%$ polyacrylamide gels. PG activity staining was performed as previously described (Moore and Bennett, 1994; Morgutti et al., 2006).

SDS-PAGE was carried out on $10 \%$ polyacrylamide gels (Schägger and von Jagow, 1987) in a MiniProtean ${ }^{\mathrm{TM}}$ apparatus. Before loading, salt-extracted proteins from the cell walls were denatured in SDS sample buffer (Laemmli, 1970). Molecular weight markers were from Sigma-Aldrich (Milan, Italy).

Western analysis was conducted as previously described (Morgutti et al., 2006). Rabbit anti-endo-PG polyclonal antibodies were raised (Primm) against a synthetic polypeptide constructed on a conserved region of the complete sequence of a Pp-endo-PG from ripe peach fruit [CAA54150 (Lester et al., 1994; Morgutti et al., 2006)].

ISOLATION OF DNA, CLONING OF AN ENDO-POLYGALACTURONASE GENE, AND GENOTYPING. Genomic DNA from young leaves (100 to $150 \mathrm{mg}$ fresh weight) was prepared according to Geuna et al. (2004). The $P p$-endo- $P G$ sequence was amplified with primers 
designed on the PRF5 endo- $P G$ cDNA sequence (Lester et al., 1994; Table S1) at the annealing temperature of $62{ }^{\circ} \mathrm{C}$. Bands obtained from the different accessions were purified, cloned into a pCR ${ }^{\circledR}$ 4-Blunt II-TOPO ${ }^{\circledR}$ vector (Invitrogen, San Giuliano, Italy), and sequenced (Primm).

To discriminate length differences (InDel polymorphisms), a region (bp 1455-1892; Fig. S1) of the Pp-endo-PG gene comprising the major InDels was amplified (primers: $\mathrm{FW}_{\mathrm{InDel}} /$ $\mathrm{R}_{\text {InDel }}$; Table S1). Restriction endonuclease digestion for cleaved amplified polymorphic sequences (CAPS) analysis was carried out with the restriction enzyme BstXI (New England Biolabs, Pero, Italy) on selected fragments (bp 1-972) from the $P p$-endo- $P G$ gene amplified with proper primers (forward: 5-ATGGCGAACCGTAGAAGCCTCT-3, reverse: 5-CCACAAGCAACGCCTTCTATCC-3). The reaction products were separated on $3 \%$ or $1 \%(\mathrm{w} / \mathrm{v})$ agarose gels and visualized by ethidium bromide staining. The polymerase chain reaction 100-bp Low Ladder (Sigma-Aldrich) and the 1-kb Plus DNA Ladder (Invitrogen) were used as molecular markers.

IdeNTIFICATION OF THE POSITIONS OF THE ISOLATEd PP-ENDO$P G$ ClONES IN THE PUBLISHED PEACH GENOME. The positions and percentages of identity with the published peach genome database (International Peach Genome Initiative, 2010) of the sequences of the isolated $P p$-endo- $P G$ clones were assessed by informatic analysis using BioEdit software [Version 7.0.5 (Hall, 1999)].

\section{Results}

Fruit firmness and ethylene evolution: Effects of ETHYLENE. The time course of softening and ethylene evolution during postharvest was studied in 'Big Top' and SH 'Ghiaccio' in the absence or in the presence of an ethylene treatment comparing their behavior with that of physiologically ripe $\mathrm{M}$ 'Bolero'. At harvest, firmness of 'Bolero' fruit was very low, whereas it was high in ripe 'Big Top' and 'Ghiaccio'. At 5 DAH, 'Big Top' firmness was very low under both air and ethylene treatment, whereas flesh melting in 'Ghiaccio' occurred only under ethylene (Table 1).

Ripe, soft M 'Bolero' fruit evolved ethylene already immediately after harvest $\left(\mathrm{t}=0 ; 9.2 \pm 3 \mu \mathrm{L} \cdot \mathrm{kg}^{-1}\right.$ fresh weight per hour) and reached the peak of ethylene emission at $5 \mathrm{DAH}$, after which it progressively decreased (Fig. 1A). At harvest, 'Big Top' did not evolve ethylene. When 'Big Top' fruit were incubated in air, ethylene evolution started at 4 DAH reaching at $9 \mathrm{DAH}$ a peak roughly comparable to that observed at $5 \mathrm{DAH}$ in M 'Bolero' (Fig. 1B). The evolution of ethylene from 'Ghiaccio' was essentially nil (Fig. 1C).

Table 1. Flesh firmness of peach fruit from different accessions at harvest and after $5 \mathrm{~d}$ of postharvest (DAH) in air or under 100 $\mathrm{mL} \cdot \mathrm{m}^{-3}$ ethylene treatment. ${ }^{\mathrm{z}}$

\begin{tabular}{lrrr}
\hline & \multicolumn{3}{c}{ Flesh firmness [mean $\pm \mathrm{SD}(\mathrm{N})]$} \\
\cline { 2 - 4 } Accession & \multicolumn{1}{c}{ Harvest } & \multicolumn{1}{c}{ Air } & Ethylene \\
\hline Bolero & $7.9 \pm 2.4$ & - & - \\
Big Top & $46.6 \pm 5.8$ & $2.5 \pm 1.1$ & $3.3 \pm 1.2$ \\
Ghiaccio & $49.6 \pm 3.9$ & $37.2 \pm 3.6$ & $4.3 \pm 2.1$ \\
\hline
\end{tabular}

${ }^{\mathrm{z}}$ Data shown were obtained from at least 10 measurements on five different fruit.

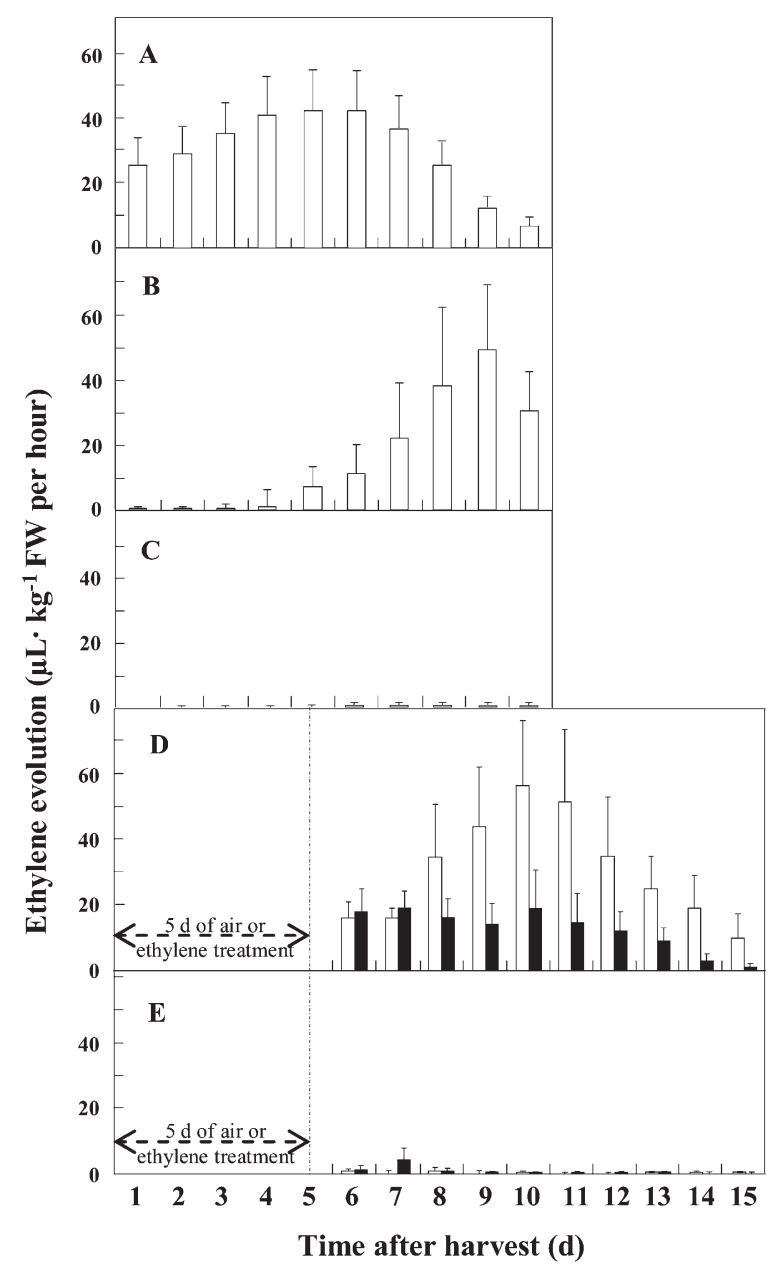

Fig. 1. Ethylene evolution by 'Bolero' (A), 'Big Top' (B and D), and 'Ghiaccio' $(\mathbf{C}$ and $\mathbf{E})$ peach fruit. (A-C) Fruit exposed to air monitored from harvest up to $10 \mathrm{~d}$ after harvest (DAH). (D-E) Fruit monitored for $10 \mathrm{~d}$ after $5 \mathrm{~d}$ in air (open bars) or $100 \mathrm{~mL} \cdot \mathrm{m}^{-3}$ ethylene (closed bars). The values are the means $\pm \mathrm{SD}$ of measurements on at least five fruit. Dotted lines in (D) and (E) show end of the 5 -d treatments.

Ethylene emission was monitored also starting from the end of the 5 -d period in air or ethylene; i.e., at $5 \mathrm{DAH}$ and for the subsequent $10 \mathrm{~d}$ [total 15 DAH (Fig. 1D-E)]. In 'Big Top' control fruit, the timing of appearance of the ethylene peak closely corresponded to that observed in the 10-d postharvest period (compare Figs. 1B and 1D). In the ethylene-treated 'Big Top' fruit, ethylene evolution was lower (Fig. 1D), possibly because of anticipation of the climacteric peak induced by the ethylene treatment. In 'Ghiaccio', ethylene evolution was almost negligible even after the 5-d ethylene treatment period (compare Figs. 1C and 1E).

EXPRESSION OF PP-ACS1 ANd PP-ACO1 In fruit Mesocarp: EFFeCts of ETHYLENE. At 5 DAH, 'Big Top' flesh firmness and ethylene emission roughly matched those observed in ripe, soft 'Bolero' fruit at harvest (Table 1; Fig. 1). This result confirmed that 'Bolero' could be taken as representative of $M$ fruit and could be used for comparison for the subsequent analyses. Figure 2 shows that in soft, ethylene-evolving 'Bolero' fruit, transcripts were present of $P p-A C S 1$ and $P p-A C O 1$. In 'Big Top', the $P p-A C S 1$ transcripts were not present at harvest but became clearly detectable at $5 \mathrm{DAH}$ in control fruit and their 


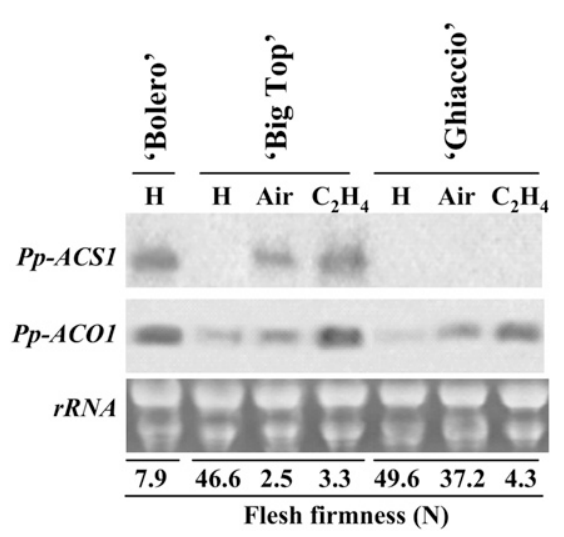

Fig. 2. $P p-A C S 1$ and $P p-A C O 1$ transcript accumulation (Northern blotting analysis) in 'Bolero', 'Big Top', and 'Ghiaccio' peach fruit at different firmness. Samples were obtained immediately after harvest $(\mathrm{H})$ and at $5 \mathrm{~d}$ after harvest $(\mathrm{DAH})$ in air or $100 \mathrm{~mL} \cdot \mathrm{m}^{-3}$ ethylene $\left(\mathrm{C}_{2} \mathrm{H}_{4}\right)$. Specific primers were used to obtain, from total RNA of ripe 'Bolero' fruit, first-strand cDNAs of conserved sequences of Pp-ACS1 [AB044662 (Mathooko et al., 2001)] and $P p-A C O 1$ [AF532976 (Moon and Callahan, 2004)]. [ $\left.\alpha-{ }^{32} \mathrm{P}\right] \mathrm{dATP}-\mathrm{labeled}$ cDNAs were used as probes. The lower panel shows the quantification image of the ethidium-bromide stained rRNA gel. Twenty micrograms of RNA was loaded per lane. One representative experiment is shown from three independent replications.

levels were higher after ethylene treatment. No expression was detected for $P p-A C S 1$ in 'Ghiaccio' in any conditions. At harvest in 'Big Top' and 'Ghiaccio' $P p-A C O 1$ transcripts were present but in lower amounts than in 'Bolero'. At 5 DAH in air, the $P p-A C O 1$ transcripts were present in both cultivars and were higher after ethylene treatment (Fig. 2).

ACTIVITY AND LEVELS OF ENDO-POLYGALACTURONASE PROTEIN ANd EXPRESSION OF a PP-ENDO-PG GENe IN FRUIT MESOCARP: Effects of ETHylene. At harvest, endo-PG activity and immunoreaction signal against a native $\mathrm{Pp}$-endo-PG were clearly detectable in soft, ethylene-producing 'Bolero' fruit but essentially undetectable in 'Big Top' and 'Ghiaccio'. At 5 DAH in air, in 'Big Top', endo-PG activity and Pp-endo-PG protein became clearly visible, whereas no increase was observed in 'Ghiaccio'. Ethylene treatment strongly increased endo-PG activity and level in 'Big Top' and induced their appearance in 'Ghiaccio' (Fig. 3). Ethylene, endogenously produced (in 'Bolero' at harvest and in 'Big Top' at 5 DAH in air) or exogenously applied (in 'Big Top' and 'Ghiaccio' at 5 DAH in ethylene), induced the appearance of an active endoPG different from that recognized by the antibodies used as indicated by a topmost band of gel decoloration (Fig. 3A) not coincident with the immunoreaction signal (Fig. 3B). The antibodies appeared to recognize two bands of active endo-PG (Fig. 3B), suggesting the presence of enzyme isoforms with a slightly different charge/mass ratio, possibly because of different post-translational modifications (Moore and Bennett, 1994).

SDS-PAGE and Western blot analysis of proteins from fruit cell walls showed, in correspondence to an $\mathrm{M}_{\mathrm{r}}$ of $\approx 45 \mathrm{kDa}$, typical of catalytically active PG forms (Brummell and Harpster, 2001; Lee et al., 1990), an immunoreaction signal clearly visible at harvest only in soft 'Bolero'. At 5 DAH in air, the Pp-endo-PG polypeptide strongly accumulated in 'Big Top', whereas it was almost undetectable in 'Ghiaccio'. At 5 DAH in ethylene, its levels increased strongly in 'Big Top' and became clearly apparent in 'Ghiaccio' (Fig. 4A). At harvest, the Pp-endo- $P G$

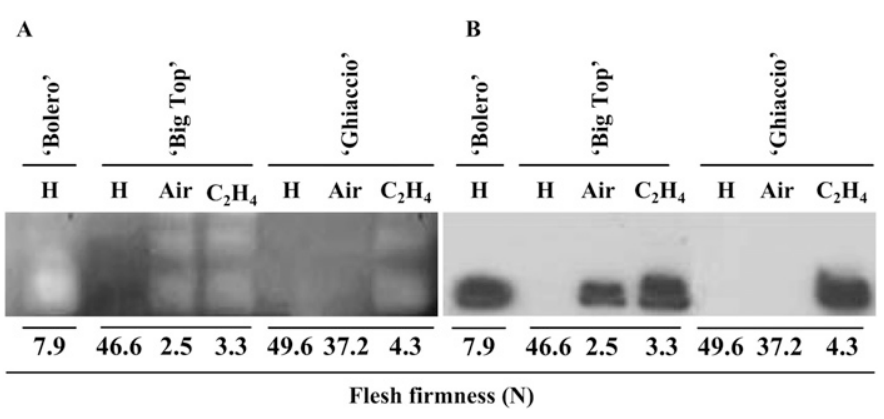

Fig. 3. Endo-PG activity (A) and levels of Pp-endo-polygalacturonase (PG) protein (B) in 'Bolero', 'Big Top', and 'Ghiaccio' peach fruit at different flesh firmness. Samples were obtained immediately after harvest $(\mathrm{H})$ and at $5 \mathrm{~d}$ after harvest (DAH) in air or $100 \mathrm{~mL} \cdot \mathrm{m}^{-3}$ ethylene $\left(\mathrm{C}_{2} \mathrm{H}_{4}\right)$. The assays were carried out after non-denaturing polyacrylamide gel electrophoresis in gels run in duplicate. Twenty micrograms of protein was loaded per lane. One representative experiment is shown from three independent replications.
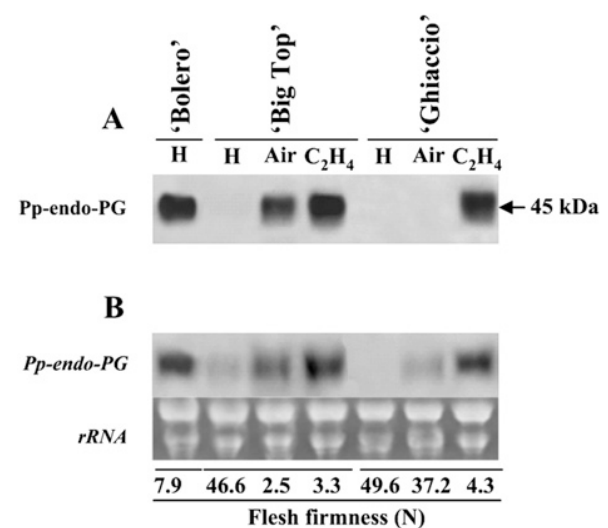

Fig. 4. Endo-PG protein [(A) sodium dodecyl sulfate-polyacrylamide gel electrophoresis/Western blotting analysis] and Pp-endo-PG transcript [(B) Northern blotting analysis] accumulation in 'Bolero', 'Big Top', and 'Ghiaccio' peach fruit at different flesh firmness. Samples were obtained immediately after harvest $(\mathrm{H})$ and at $5 \mathrm{~d}$ after harvest (DAH) in air or 100 $\mathrm{mL} \cdot \mathrm{m}^{-3}$ ethylene $\left(\mathrm{C}_{2} \mathrm{H}_{4}\right)$. Twenty micrograms of protein or RNA was loaded per lane. For Western blotting analysis, anti-endo-PG polyclonal antibodies designed on a conserved region of Pp-endo-PG from ripe peach fruit were used. For Northern blotting analysis, specific primers [PRF5 (Lester et al., 1994)] were used to obtain, from total RNA of ripe 'Bolero' fruit, first-strand complete cDNA of $P p$-endo- $P G$. This $\left[\alpha-{ }^{32} \mathrm{P}\right] \mathrm{dATP}-$ labeled cDNA was used as a probe. In (B), the quantification image of the ethidium-bromide stained rRNA gel is also shown. The results of one representative experiment from three independent replications are shown.

transcripts were very abundant in soft 'Bolero', barely present in 'Big Top', and undetectable in 'Ghiaccio'. Transcript accumulation showed an increase at $5 \mathrm{DAH}$ in control fruit (apparent in 'Big Top' and fainter in 'Ghiaccio') and was distinctly promoted by ethylene treatment (Fig. 4B).

Structure of a PP-ENDo-PG Gene in Diverse PeACH accessions. The molecular features of a $P p$-endo- $P G$ gene involved in peach softening (Callahan et al., 2004; Lester et al., 1996; Morgutti et al., 2006) were studied in 'Bolero', 'Big Top', and 'Ghiaccio'. 'Oro A' and 'Yumyeong' were also considered as reference NM and SH genotypes. Four exons and three introns were deduced in the putative $P p$-endo- $P G$ sequences from comparison with those of the $P p$-endo- $P G$ cDNAs previously identified (Morgutti et al., 2006). A single $P p$-endo- $P G$ clone ( $m-O, 2238 \mathrm{bp}$ ) was isolated in NM 'Oro A', 
whereas two clones ( $m-B$ and $M$ ) were isolated in M 'Bolero', consistent with previous findings (Morgutti et al., 2006). Although $m-O$ and $m-B$ were coincident, the clone $M$ showed four deletions in intronic sequences (bp 688-690, 1541-1557, 1756-1772, 1907-1908), one insertion, and 39 SNPs when compared with the clones $m$ and in toto was shorter by $37 \mathrm{bp}$. Only one (bp 1756-1772) of the two 17-bp deletions of the clone $M$ of 'Bolero' was conserved in 'Big Top', 'Ghiaccio', and 'Yumyeong'. Furthermore, the 'Big Top' $P$ p-endo- $P G$ clone $(B T)$ showed 62 SNPs in comparison with the clone $M$ and five SNPs when compared with 'Ghiaccio' and 'Yumyeong' (SH clone). The exonic $\mathrm{SNP}_{348}$ was peculiar to 'Big Top' and the intronic $\mathrm{SNP}_{1146}$ to 'Yumyeong' and 'Ghiaccio' (Figs. 5 and S1).

INSERTION-DELETION AND CLEAVED AMPLIFIED POLYMORPHIC SEQUenCes ANAlysis OF SELECTED PP-ENDO-PG SEQUenCeS. Intron 3 of $P$-endo- $P G$ showed the most polymorphisms among the accessions considered (Fig. S1). When a short (436 bp) sequence comprising these major differences was amplified, 'Oro A' produced a single fragment of $\approx 440 \mathrm{bp}$, consistent with the length predicted from in silico analysis. 'Bolero' yielded two fragments of $\approx 440$ and $400 \mathrm{bp}$ (predicted 436 and $402 \mathrm{bp}$ ), whereas 'Big Top', 'Ghiaccio', and 'Yumyeong' produced only one fragment of $\approx 420 \mathrm{bp}$ (predicted $420 \mathrm{bp}$ for 'Big Top' and $419 \mathrm{bp}$ for the other accessions; Fig. 6A).

The peculiar exonic $\mathrm{SNP}_{348}\left[\mathrm{C} \rightarrow \underline{\mathrm{T}}_{B T}\right.$ (Figs. 5 and $\left.\left.\mathrm{S} 1\right)\right]$ of the 'Big Top' $P p$-endo- $P G$ clone originated a sequence (CCANNNNN ${ }^{\mathbf{}}$ NTGG) recognized by the restriction enzyme BstXI. A Pp-endo-PG fragment comprising this SNP (bp 1972) was amplified and digested with BstXI. CAPS reaction yielded two bands of $\approx 350$ and 600 bp only in 'Big Top', consistent with the lengths [348 and 624 bp, respectively (Fig. 5)] predictable for the fragments obtainable by the action of this endonuclease, which was not effective on all the other accessions (Fig. 6B).

\section{Discussion}

Our results show that, although at physiological ripening texture of 'Big Top' fruit is very similar to that of $\mathrm{SH}$ ones, during postharvest the behavior of 'Big Top' was very different from that of SH 'Ghiaccio'. In fact, 'Big Top' did evolve ethylene, even if late, in postharvest [5 DAH in air (Fig. 1B)], concomitant with increased $P p$-ACS1 (Fig. 2) and $P p$-endo- $P G$ transcript levels (Fig. 4B) and production of an active endo-PG protein (Figs. 3 and 4A), finally leading to fruit melting (Table 1). On the contrary, SH 'Ghiaccio' fruit in air failed to evolve ethylene apparently as a consequence of a blockade of the expression of $P p$ - $A C S 1$, known to play a crucial role in ethylene evolution during ripening (Mathooko et al., 2001; Tatsuki et al., 2006). These features were accompanied by poor endo-PG production and very limited softening. Nevertheless, the ethylene treatment on 'Ghiaccio', although showing no effect on the accumulation of $P p-A C S 1$ transcripts and a very limited one on ethylene evolution, led to a dramatic increase in endoPG production with fruit melting (Figs. 1 through 4), consistent with data from the literature (Begheldo et al., 2008; Haji et al., 2005; Tatsuki et al., 2006).

At 5 DAH, 'Big Top' fruit seemed very comparable to the M 'Bolero' ones harvested at physiological ripening, in which low firmness was accompanied by high levels of $P p$-ACS1 transcripts, high ethylene evolution, activation of a $P p$-endo- $P G$ gene, and production of high levels of an active endo-PG protein (Figs. 1 through 4). These findings support previous observations (Bassi and Monet, 2008; Lavilla et al., 2002) and confirm that 'Big Top' fruit belong to the melting phenotype and that their slow-melting characteristics are the result of delayed $P p$-ACS1 activation and ethylene evolution.

The timing of postharvest ethylene evolution in fruit can vary even within the same species depending on many factors, among which morphological traits (Ezura and Owino, 2008), seed presence/absence (Hershkovitz et al., 2010), and fruit developmental stage at harvest (as reported in peach: Haji et al., 2004; Lavilla et al., 2002) are all able to affect the expression of members of the $A C S$ and $A C O$ multifamilies (Bleecker and Kende, 2000; Kende, 1993). 'Big Top' fruit soften on the tree at a slower pace than other peach cultivars (Bassi et al., 2008; Iglesias and Echeverría, 2009). At the moment, it is not possible to speculate on the nature of the factor(s) and the mechanism(s) that may differently affect, in $\mathrm{M}$ 'Bolero' and in 'Big Top', the timing of activation of $P p$-ACS1.

The mere amounts of fruit ethylene evolution may not represent the 
only point of control for ethylene-regulated, endo-PG-dependent softening. In peach, NM fruit evolve more ethylene than $\mathrm{M}$ ones (Brovelli et al., 1999). Differences may depend on the ability of the fruit tissues to perceive ethylene, transduce its signal, or both (Ghiani et al., 2007; Morgutti et al., 2005) up to the final regulation of the expression of the target gene(s). The recently described cross-talk between ethylene and other phytoregulators in fruit ripening further complicates the overall picture (El-Sharkawy et al., 2009; Trainotti et al., 2007; Villarreal et al., 2009).

It is interesting to stress that in fruit of all the accessions studied, ethylene induced the appearance of an active endo-PG not recognized by the antibodies used (Fig. 3A-B), which may be ascribable to other forms of the enzyme. In ethylene-treated soft peaches, a $P G$ transcript has been described [PpPG1, AB231902 (Murayama et al., 2009)] whose deduced protein shares only $36 \%$ similarity with that taken as a reference for the development of the antibodies used in the present study (Lester et al., 1994).

In NM and $\mathrm{M}$ peaches, different softening has been related to specific features of a $P p$-endo- $P G$ gene expressed in ripe fruit [ $M$ locus, also controlling the Freestone trait (Callahan et al., 2004; Lester et al., 1996; Morgutti et al., 2006; Peace et al., 2005, 2007)] independent of ethylene evolution (Brovelli et al., 1999). On the other hand, SH peaches have been classified as $h d h d M$ - and hdhdmm discriminating the asset at the endo-PG locus on the basis of their ability to melt when treated with ethylene (Haji et al., 2005). Therefore, we considered it interesting to investigate the molecular features of the 'Big Top' $P$ p-endo- $P G$ gene and to compare them with those of $\mathrm{SH}$ 'Ghiaccio' and 'Yumyeong' and of two reference accessions for NM ('Oro A') and M ('Bolero') phenotypes (Morgutti et al., 2006). The 'Big Top' $P p$-endo- $P G$ clone was very similar to those of 'Ghiaccio' and 'Yumyeong', whereas it presented many polymorphisms compared with the clone $M$ of 'Bolero' (Fig. S1). Comparison with the recently published peach genome sequence (International Peach Genome Initiative, 2010) gave consistent results. The $m-O$ and $m-B$ Pp-endo- $P G$ clones showed $100 \%$ identity with a sequence (ppa006839m) located at bp 22,650,221 on the peach genome scaffold_4, whereas identity of the 'Big Top', 'Ghiaccio', and 'Yumyeong' sequences was 97\%. The $M$ endo- $P G$ clone of 'Bolero' showed $100 \%$ identity with a duplicate sequence (ppa006857m) located on the same scaffold_4 but at bp 22,684,623 (Fig. 7).

An analysis of the $P p$-endo- $P G$ exonic sequences in the different accessions showed that in 'Big Top' they were identical to those of 'Ghiaccio' and 'Yumyeong' apart from the 'Big Top' $\mathrm{SNP}_{348}$ (Figs. 5 and S1), which does not determine any change in the amino acidic sequence of the corresponding deduced protein. Because of a $\mathrm{C}$ replacing a $\mathrm{G}$ $\left(\mathrm{SNP}_{1310}\right)$ in $m-O, m-B, B T$, and $S H$ clones, the deduced endo-PG proteins differed from that encoded by the $M P p$-endo- $P G$ clone of 'Bolero' only for a $\mathrm{Thr}_{269}$ replacing a $\mathrm{Ser}_{269}$. The reported biochemical and physiological results concerning the ability of 'Big Top' and 'Ghiaccio' to produce an active endo-PG and melt when ethylene is present (Fig. 3) suggest that this amino acidic substitution does not deeply affect the enzyme activity. In 'Oro A', poor endo-PG activity might be possibly related to the substitution of a $\operatorname{Ser}_{\text {Bol49 }}$ with

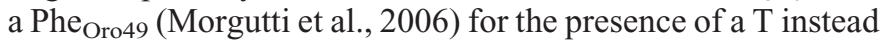
of a $\mathrm{C}$ at $146 \mathrm{bp}$ in the $m$ clones, even if an influence of possible different post-translational modifications cannot be excluded. Moreover, the possibility of a diminished response to ethylene in the 'Oro A' high ethylene-producing fruit might be ascribed to possible differences in the $P p$-endo- $P G$ promoter sequences.

SNPs and intronic InDel polymorphisms are currently used for phylogenetic and parentage analyses (Wei et al., 2006) or identification of cultivar/lines in plants (Shimada et al., 2009). The $\mathrm{SNP}_{348}$ peculiar to 'Big Top' and the InDel polymorphisms common to 'Big Top', 'Ghiaccio', and 'Yumyeong' (Figs. 5, $6 \mathrm{~A}, 6 \mathrm{~B}$, and $\mathrm{S} 1$ ) seem suitable for use as molecular markers. If

A

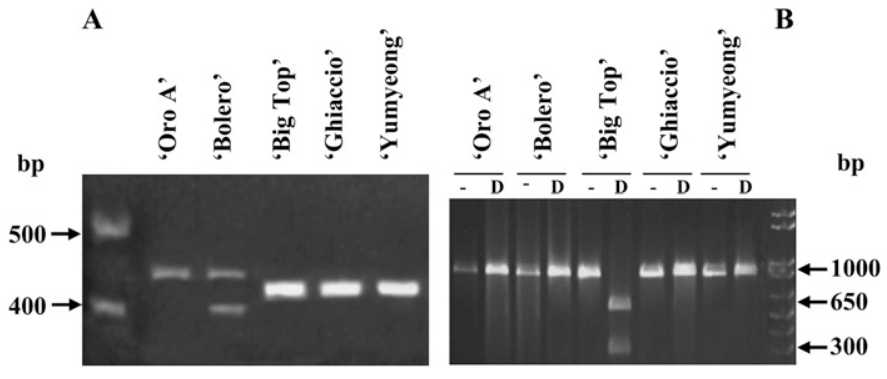

Fig. 6. Amplification of a selected fragment (A) and cleaved amplified polymorphic sequences (CAPS) restriction patterns (B) of genomic DNA from leaves of 'Oro A', 'Bolero', 'Big Top', 'Ghiaccio', and 'Yumyeong' peach accessions. (A) A region (bp 1455-1892) of the $P p$-endo- $P G$ gene was amplified with specific primers $\left[\mathrm{FW}_{\text {InDel }} / \mathrm{R}_{\text {InDel }}\right.$ (Table S1)]. Positions and lengths of DNA markers (polymerase chain reaction 100-bp Low Ladder; Sigma-Aldrich, Milan, Italy) are shown on the left. (B) Selected genomic sequences (bp 1-972) of the Pp-endo- $P G$ clones were amplified with proper primers (forward: 5-ATGGCGAACCGTAGAAGCCTCT-3, reverse: 5CCACAAGCAACGCCTTCTATCC-3) and digested with BstXI. (-), undigested; (D) BstXI-digested. Positions and lengths of DNA markers (1 kb Plus DNA ladder; Invitrogen, San Giuliano, Italy) are shown on the right. In both experiments, $20 \mu \mathrm{g}$ of DNA was loaded per lane; the products were separated on $3 \% \mathrm{w} / \mathrm{v}(\mathbf{A})$ or $1 \% \mathrm{w} / \mathrm{v}$ (B) agarose gels. The results of one representative experiment from three independent replications are shown.

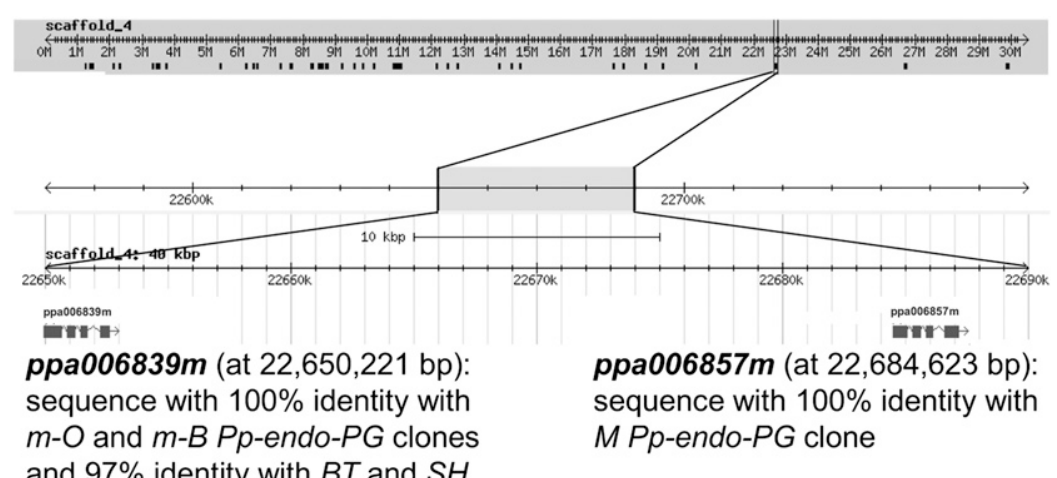
and $97 \%$ identity with $B T$ and $S H$ endo- $P G$ clones

Fig. 7. Schematic map of $40 \mathrm{kbp}$ (positions $22,650,000-22,690,000 \mathrm{bp}$ ) from scaffold_4 of the peach genome (modified from International Peach Genome Initiative. 2010). This region of this scaffold reports two sequences showing $100 \%$ identity with the $P p$-endo- $P G$ clones $m-O$ ('Oro A') and $m-B$ ('Bolero') and $97 \%$ identity with the $B T$ ('Big Top') and $S H$ ('Ghiaccio' and 'Yumyeong') clones (ppa006839m at 22,650,221 bp) and $100 \%$ identity with the $M$ clone of 'Bolero' (ppa006857m at $22,684,623 \mathrm{bp})$. The percentages of identity of the sequences were assessed using BioEdit software [Version 7.0.5 (Hall, 1999)]. 
confirmed on other accessions that show the fruit slow-melting phenotype of 'Big Top', our preliminary findings may represent diagnostic tools to discriminate among genotypes or segregating progenies (for molecular-assisted breeding) or to ascertain whether a selection is genetically related to 'Big Top'. Further analysis on populations segregating for fruit texture characteristics is necessary to validate this SNP marker.

In conclusion, our data seem to confirm the pivotal role of ethylene in the regulation of endo-PG production and in the determination of peach fruit texture in different phenotypes (for reviews, see Bennett and Labavitch, 2008; Inaba, 2007). The peculiar slow-melting characteristics of 'Big Top' seem related not to differences in the $P p$-endo- $P G$ clone considered, but to delayed $P p-A C S 1$ expression, ethylene evolution, endo-PG production, and melting of the flesh. All these features seem to cooperate in determining the remarkable ability of these fruit to develop satisfactory organoleptic qualities while better withstanding the postharvest operations.

\section{Literature Cited}

Bailey, J.S. and A.P. French. 1949. The inheritance of certain fruit and foliage characters in the peach. Massachusetts Agr. Expt. Sta. Bul. 452. Bassi, D., A. Ghiani, I. Mignani, S. Morgutti, N. Negrini, A. Spinardi, D. Giovannini, A. Liverani, S. Foschi, and M. Rizzo. 2008. 'Big Top' nectarine, a case study for flesh texture, p. 20-27. In: Di Vaio, C., C. Damiano, and C. Fideghelli (eds.). Proc. 6th Natl. Symp. on "Peschicoltura Meridionale." Regione Campania-Assessorato all'Agricoltura, Naples, Italy.

Bassi, D. and R. Monet. 2008. Botany and taxonomy, p. 1-36. In: Layne, D.R. and D. Bassi (eds.). The peach: Botany, production and uses. CAB Intl., Wallingford, UK.

Begheldo, M., G. Manganaris, C. Bonghi, and P. Tonutti. 2008. Different postharvest conditions modulate ripening and ethylene biosynthetic and signal transduction pathways in stony hard peaches. Postharvest Biol. Technol. 48:84-91.

Benedetti, S., S. Buratti, A. Spinardi, S. Mannino, and I. Mignani. 2008. Electronic nose as a non-destructive tool to characterise peach cultivars and to monitor their ripening stage during shelf-life. Postharvest Biol. Technol. 47:181-188.

Bennett, A.B. and J.M. Labavitch. 2008. Ethylene and ripeningregulated expression and function of fruit cell wall modifying proteins. Plant Sci. 175:130-136.

Bleecker, A.B. and H. Kende. 2000. Ethylene: A gaseous signal molecule in plants. Annu. Rev. Cell Dev. Biol. 16:1-18.

Bradford, M.M. 1976. A rapid and sensitive method for the quantitation of microgram quantities of protein utilizing the principle of protein-dye binding. Anal. Biochem. 72:248-254.

Brovelli, E.A., J.K. Brecht, W.B. Sherman, and C.A. Sims. 1999. Nonmelting-flesh trait in peaches is not related to low ethylene production rates. HortScience 34:313-315.

Brummell, D.A., V. Dal Cin, C.H. Crisosto, and J.M. Labavitch. 2004. Cell wall metabolism during maturation, ripening and senescence of peach fruit. J. Expt. Bot. 55:2029-2039.

Brummell, D.A. and M.H. Harpster. 2001. Cell wall metabolism in fruit softening and quality and its manipulation in transgenic plants. Plant Mol. Biol. 47:311-340.

Callahan, A.M., R. Scorza, C. Bassett, M. Nickerson, and F.B. Abeles. 2004. Deletions in an endopolygalacturonase gene cluster correlate with non-melting flesh texture in peach. Funct. Plant Biol. 31:159168.

Cantín, C.M., Y. Gogorcena, and M.A. Moreno. 2010. Phenotypic diversity and relationships of fruit quality traits in peach and nectarine [Prunus persica (L.) Batsch] breeding progenies. Euphytica 171:211-226.

Cara, B. and J.J. Giovannoni. 2008. Molecular biology of ethylene during tomato fruit development and maturation. Plant Sci. 175:106-113.
Crisosto, C.H. 1994. Stone fruit maturity indices: A descriptive review. Postharvest News Info. 5:65-68.

Crisosto, C.H., D. Slaughter, D. Garner, and J. Boyd. 2001. Stonefruit critical bruising thresholds. J. Amer. Pomol. Soc. 55:76-81.

Delwiche, M.J. and R.A. Baumgardner. 1985. Ground color as a peach maturity index. J. Amer. Soc. Hort. Sci. 110:53-57.

El-Sharkawy, I., S. Sherif, I. Mila, M. Bouzayen, and S. Jayasankar. 2009. Molecular characterization of seven genes encoding ethyleneresponsive transcriptional factors during plum fruit development and ripening. J. Expt. Bot. 60:907-922.

Ezura, H. and W.O. Owino. 2008. Melon, an alternative model plant for elucidating fruit ripening. Plant Sci. 175:121-129.

Gamberini, A. 2007. Molecular markers and controlling genes of peach flesh texture. PhD diss., Bologna Univ., Bologna, Italy.

Geuna, F., C. Maitti, S. Digiuni, and R. Banfi. 2004. A method for the extraction of genomic DNA from plant tissues rich in contaminating compounds suitable for medium-throughput applications. Plant Mol. Biol. Rpt. 22:1-5.

Ghiani, A., N. Negrini, S. Morgutti, F.F. Nocito, A. Spinardi, C. Ortugno, I. Mignani, D. Bassi, and M. Cocucci. 2007. Flesh softening in melting flesh, non melting flesh and stony hard peaches: Endopolygalacturonase expression and phosphorylation of soluble polypeptides in relation to ethylene production, p. 175-180. In: Ramina, A., C. Chang, J. Giovannoni, H. Klee, P. Perata, and E. Woltering (eds.). Advances in plant ethylene research. Proc. 7th Intl. Symp. on the Plant Hormone Ethylene. Springer, Dordrecht, The Netherlands.

Haji, T., H. Yaegaki, and M. Yamaguchi. 2003. Softening of stony hard peach by ethylene and the induction of endogenous ethylene by 1-aminocyclopropane-1-carboxylic acid (ACC). J. Jpn. Soc. Hort. Sci. 72:212-217.

Haji, T., H. Yaegaki, and M. Yamaguchi. 2004. Varietal differences in relationship between maturation characteristics, storage life and ethylene production in peach fruit. J. Jpn. Soc. Hort. Sci. 73: 97-104.

Haji, T., H. Yaegaki, and M. Yamaguchi. 2005. Inheritance and expression of fruit texture melting, non-melting and stony hard in peach. Sci. Hort. 105:241-248.

Hall, T.A. 1999. BioEdit: A user-friendly biological sequence alignment editor and analysis program for Windows 95/98/NT. Nucleic Acids Symp. Ser. 41:95-98.

Hayama, H., T. Shimada, H. Fujii, A. Ito, and Y. Kashimura. 2006a. Ethylene-regulation of fruit softening and softening-related genes in peach. J. Expt. Bot. 57:4071-4077.

Hayama, H., M. Tatsuki, A. Ito, and Y. Kashimura. 2006b. Ethylene and fruit softening in the 'stony hard' mutation in peach. Postharvest Biol. Technol. 41:16-21.

Hershkovitz, V., H. Friedman, E.E. Goldschmidt, and E. Pesis. 2010. Ethylene regulation of avocado ripening differs between seeded and seedless fruit. Postharvest Biol. Technol. 56:138-146.

Iglesias, I. and G. Echeverría. 2009. Differential effect of cultivar and harvest date on nectarine colour, quality and consumer acceptance. Sci. Hort. 120:41-50.

Inaba, A. 2007. Studies on the internal feedback regulation of ethylene biosynthesis and signal transduction during fruit ripening, and the improvement of fruit quality. J. Jpn. Soc. Hort. Sci. 76:1-12.

International Peach Genome Initiative. 2010. Peach Genome Version 1. 22 Oct. 2010. <http://www.rosaceae.org/sites/www.rosaceae.org/ files/Prunus_persica.main_genome.scaffolds.fasta>.

Kende, H. 1993. Ethylene biosynthesis. Annu. Rev. Plant Physiol. Plant Mol. Biol. 44:283-307.

Kim, Y.H., M.D. Cho, D.K. Lee, and Y.S. Yu. 1978. The new peach cultivar 'Yumyeong'. Res. Rpt. Office Rural Dev. Hort. Agr. Eng. $20: 1-5$

Laemmli, U.K. 1970. Cleavage of structural proteins during the assembly of the head of bacteriophage T4. Nature 227:680-685.

Lavilla, T., I. Recasens, M.L. Lopez, and J. Puy. 2002. Multivariate analysis of maturity stages, including quality and aroma, in 'Royal 
Glory’ peaches and 'Big Top' nectarines. J. Sci. Food Agr. 82:18421849

Lee, E., J. Speirs, and C.J. Brady. 1990. Homologies to the tomato endopolygalacturonase gene in the peach genome. Plant Cell Environ. 13:513-521.

Lester, D.R., W.B. Sherman, and B.J. Atwell. 1996. Endopolygalacturonase and the melting flesh (M) locus in peach. J. Amer. Soc. Hort. Sci. 121:231-235.

Lester, D.R., G. Speirs, G. Orr, and C.J. Brady. 1994. Peach (Prunus persica) endo- $P G$ cDNA isolation and mRNA analysis in melting and non-melting peach cultivars. Plant Physiol. 105:225-231.

Liverani, G., D. Giovanini, F. Brandi, and M. Merli. 2003. Le pesche subacide. L'Informatore Agrario 31:43-49.

Loulakakis, K.A., K.A. Roubelakis-Angelakis, and A.K. Kanellis. 1996. Isolation of functional RNA from grapevine tissues poor in nucleic acid content. Amer. J. Enol. Viticult. 47:181-185.

Mathooko, F.M., Y. Tsunashima, W.Z.O. Owino, Y. Kubo, and A. Inaba. 2001. Regulation of genes encoding ethylene biosynthetic enzyme in peach (Prunus persica L.) fruit by carbon dioxide and 1methylcyclopropene. Postharvest Biol. Technol. 21:265-281.

Monet, R. 1979. Transmission génétique du caractère "fruit doux" chez le pêcher. Incidence sur la sélection pour la qualité. Proc. Eucarpia Fruit Section Symposium. Tree Fruit Breeding. Institut National de la Recherche Agronomique, Angers, France. p. 273-276. Moon, H. and A.M. Callahan. 2004. Developmental regulation of peach ACC oxidase promoter-GUS fusions in transgenic tomato fruits. J. Expt. Bot. 55:1519-1528.

Moore, T. and A.B. Bennett. 1994. Tomato fruit polygalacturonase isozyme 1 . Characterization of the $\beta$ subunit and its state of assembly in vivo. Plant Physiol. 106:1461-1469.

Morgutti, S., N. Negrini, I. Mignani, D. Bassi, and M. Cocucci. 2005. Flesh softening and phosphorylation of soluble polypeptides in relation to ethylene production in Prunus persica fruits with different ripening patterns. Acta Hort. 682:155-162.

Morgutti, S., N. Negrini, F.F. Nocito, A. Ghiani, D. Bassi, and M. Cocucci. 2006. Changes in endopolygalacturonase levels and characterization of a putative endo- $P G$ gene during fruit softening in peach genotypes with nonmelting and melting flesh fruit phenotypes. New Phytol. 171:315-328.

Murayama, H., M. Arikawa, Y. Sasaki, V. Dal Cin, W. Mitsuhashi, and T. Toyomasu. 2009. Effect of ethylene treatment on expression of polyuronide-modifying genes and solubilization of polyuronides during ripening in two peach cultivars having different softening characteristics. Postharvest Biol. Technol. 52:196-201.

Nicotra, A., L. Conte, L. Moser, and P. Fantechi. 2002. New types of high quality peaches: Flat peaches ( $P$. persica var. Platicarpa) and 'Ghiaccio' peach series with long on tree fruit life. Acta Hort. 592:131-135.

Orr, G. and C. Brady. 1993. Relationship of endopolygalacturonase activity to fruit softening in a freestone peach. Postharvest Biol. Technol. 3:121-130.
Peace, C.P., A.M. Callahan, E.A. Ogundiwin, D. Potter, T.M. Gradziel, F.A. Bliss, and C.H. Crisosto. 2007. Endopolygalacturonase genotypic variation in Prunus. Acta Hort. 738:639-646.

Peace, C.P., C.H. Crisosto, and T.M. Gradziel. 2005. Endopolygalacturonase: A candidate gene for freestone and melting flesh in peach. Mol. Breed. 16:21-31.

Pressey, R. and J.K. Avants. 1978. Differences in polygalacturonase composition of clingstone and freestone peaches. J. Food Sci. 43: $1415-1423$

Robertson, J.A., R.J. Horvat, B.G. Lyon, F.I. Meredith, S. Senter, and W.R. Okie. 1990. Comparison of quality characteristics of selected yellow- and white-fleshed peach cultivars. J. Food Sci. 55:1308-1311.

Schägger, H. and G. von Jagow. 1987. Tricine-sodium dodecyl sulfate-polyacrylamide gel electrophoresis for the separation of proteins in the range from 1 to $100 \mathrm{kDa}$. Anal. Biochem. 166:368379.

Shimada, N., T. Nakatsuka, Y. Nakano, Y. Kakizaki, Y. Abe, T. Hikage, and M. Nishihara. 2009. Identification of gentian cultivars using SCAR markers based on intron-length polymorphisms of flavonoid biosynthetic genes. Sci. Hort. 119:292-296.

Tatsuki, M., T. Haji, and M. Yamaguchi. 2006. The involvement of 1aminocyclopropane-1-carboxylic acid synthase isogene, Pp-ACS1, in peach fruit softening. J. Expt. Bot. 57:1281-1289.

Tatsuki, M., T. Haji, and M. Yamaguchi. 2007. The peach 1-aminocyclopropane-1-carboxylic acid synthase isogene, $P p-A C S 1$, is required for fruit softening, p. 227-228. In: Ramina, A., C. Chang, J. Giovannoni, H. Klee, P. Perata, and E. Woltering (eds.). Advances in plant ethylene research. Proc. 7th Intl. Symp. on the Plant Hormone Ethylene. Springer, Dordrecht, The Netherlands.

Tonutti, P., C. Bonghi, and A. Ramina. 1996. Fruit firmness and ethylene biosynthesis in three cultivars of peach (Prunus persica L. Batsch.). J. Hort. Sci. 71:141-147.

Trainotti, L., A. Tadiello, and G. Casadoro. 2007. The involvement of auxin in the ripening of climacteric fruits comes of age: The hormone plays a role of its own and has an intense interplay with ethylene in ripening peaches. J. Expt. Bot. 58:3299-3308.

Trainotti, L., D. Zanin, and G. Casadoro. 2003. A cell wall-oriented genomic approach reveals a new and unexpected complexity of the softening in peaches. J. Expt. Bot. 54:1821-1832.

Villarreal, N.M., G.A. Martínez, and P.A. Civello. 2009. Influence of plant growth regulators on polygalacturonase expression in strawberry fruit. Plant Sci. 176:749-757.

Wei, H., Y. Fu, and R. Arora. 2006. Utilization of intron-flanking ESTspecific markers in the phylogenetic analysis and parentage identification of Rhododendron species and hybrids. J. Amer. Soc. Hort. Sci. 131:814-819.

Westwood, M.N. 1978. Temperate-zone pomology. Freeman, San Francisco, CA.

Yoshida, M. 1976. Genetical studies on the fruit quality of peach varieties. III. Texture and keeping quality. Bul. Fruit Tree Res. Sta. (Hiratsuka, Japan) 3:1-16. 


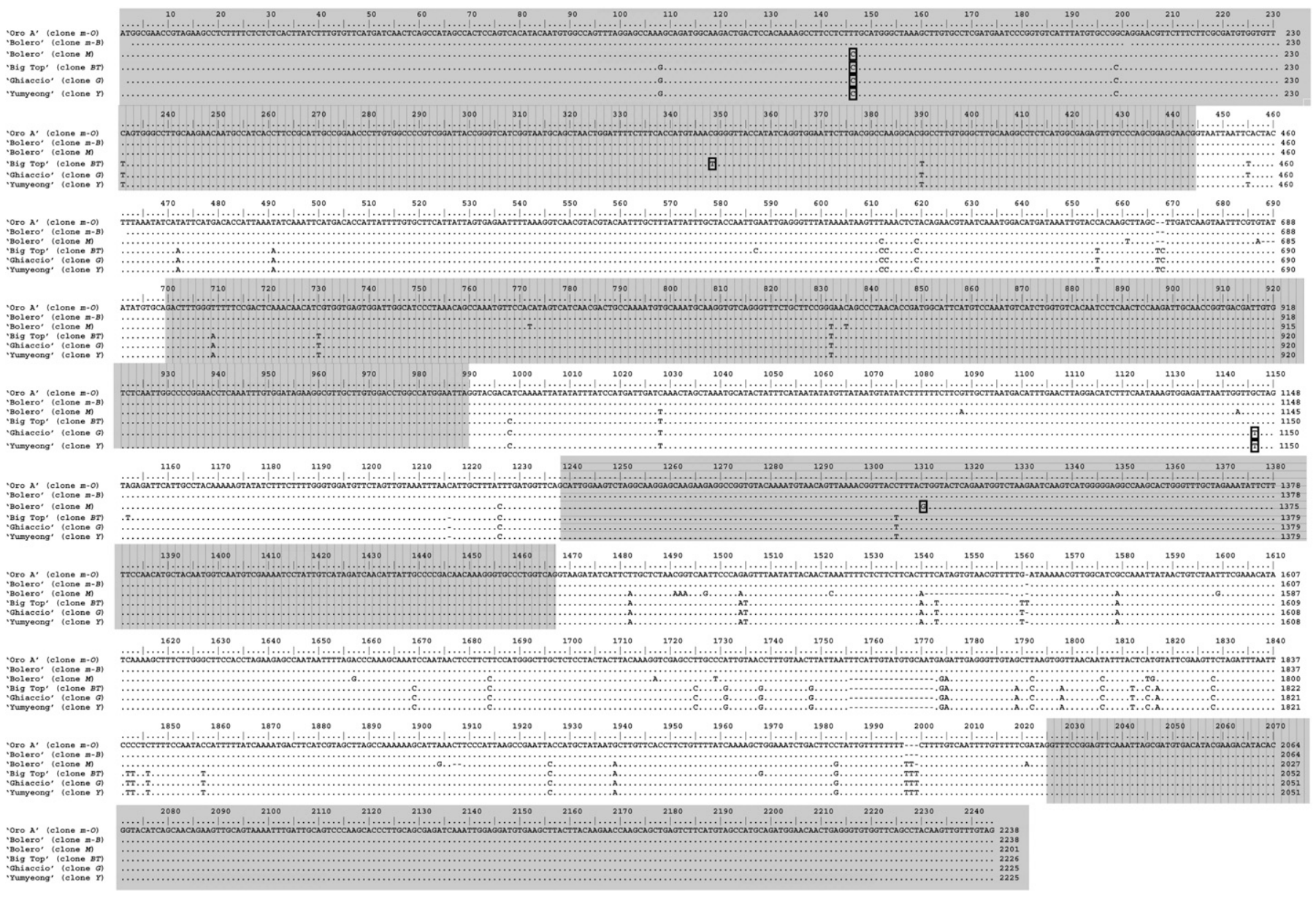

Fig. S1. Multiple sequence alignment of $P p$-endo- $P G$ clones isolated from 'Oro A' (NM), 'Bolero' (M), 'Big Top', 'Ghiaccio' (SH), and 'Yumyeong' (SH) peach accessions. Sequences shaded in gray indicate exons; unshaded sequences indicate introns as deduced from the sequences of the $P p-e n d o-P G \mathrm{cDNAs}$ from 'Oro A' and 'Bolero' (GenBank DQ340810 and DQ340809, respectively). In evidence (bold frame) the nucleotides originating $\mathrm{SNP}_{146}, \mathrm{SNP}_{348}, \mathrm{SNP}_{1146}$, and SNP 1310 .

Table S1. Primers (FW = forward; $\mathrm{R}=$ reverse) for Northern analysis of gene expression ( $P p$-endo- $P G, P p$ - $A C S 1, P p$ - $A C O 1)$ or amplification of selected $P p$-endo- $P G$ gene sequences (InDel) in peach fruit mesocarp.

\begin{tabular}{lcl}
\hline Gene name/gene sequence & Reference/GenBank no. & \multicolumn{1}{c}{ Primer FW/R } \\
\hline$P p$-endo-PG & Lester et al., 1994 & 5-ATGGCGAACCGTAGAAGCCTCT-3 \\
& & 5-CTACAAACAACTTGTAGGCTGAAC-3 \\
$P p$-ACS1 & AB044662 & 5-ATGGGCTCCTCATCAGCAAC-3 \\
& & 5-TTAAGTCTTGGCTCGAACGAGAGG-3 \\
$P p$ - $A C O 1$ & AF532976 & 5-ATGGAGAACTTCCCAATCATCAAC-3 \\
$P p$-endo- $P G_{\text {InDel }}$ & & 5-TTAAGCTGTTGCAATTGGACCC-3 \\
& DQ659240 & 5-GTGCCCTGGTCAGGTAAG-3 \\
\hline
\end{tabular}

InDel $=$ insertion-deletion 